\title{
RESEARCHING AND TEACHING LOCAL HISTORY \\ AT THE COLLEGE LEVEL
}

\author{
Bullitt Lowry \\ North Texas State University
}

Like the reputation of military history as a forum in which retired colonels can fight their favorite bloodbaths one more time, the study of local history has been caricatured too long as the property of little old ladies baying on the trail of their ancestors. This situation is changing. In recent years professional historians have shown an increased interest in local history, a trend which began in European studies, and recent scholarship has illustrated the value of that local approach. ${ }^{1}$ Reinforcing the trend to local history has been the rise of quantitative studies, where it quickly became apparent that the most useful information was that which concerned local and regional areas. 2 In American scholarship, the development of the whole subfield of urban history put new emphasis on local history. ${ }^{3}$ The most recent edition of the Harvard Guide to American History notes the new forces acting on the field of local history, 4 but the revolution has been going on for some time. During the last three decades, for example, local studies have forced a re-definition of the Anerican Progressive movement. 5

other considerations also recommend the study of local history. First, it is pre-eminently the story of the "inarticulate," and for scholars concerned. with matters other than the "names of kings," or those who wish to look at the lives of persons whose "names are not written in bronze/Nor their rowing sticks set with Elpenor's," local history forces a concentration upon the lives and dreams of ordinary persons. 6 "The most conservative standards of evidence and proof require that historiography include a history of the inarticulate," Jesse Lemisch reminds us.7 A second recommendation for local history is one that can only be offered with diffidence. History is not a science for any number of reasons, one of which is that historians have no true way to test their hypotheses. It is possible that local history, through its multiplication of events, can provide more rigid tests of hypotheses than those to which historians usually subject their ideas.

For these reasons, local history is a useful and increasingly accepted branch of the historical discipline; at the same time, it appears to be an overlooked tool on the teacher's workbench. 8 Few colleges or universities offer courses directly on local history, and the state histories they do offer apparently are seen as a service for the certification of aspiring public school teachers, who are exhorted to use the resources of local history in the grades. 9 But at the college leve1, professors dismiss, implicitly at least, the advantages that training in local history could bring to their students.

Students, both elementary and advanced, need convincing that history is real. 10 The esoteric knowledge the student absorbs about the rise of capitalism or peasant rebellions gains concrete reality when he discovers analogies to those far-away events in the impact of the railroad upon some we11-known small town, or when he sees the changes in land use and ownership that follow changes in agricultural technology locally. One of the cardinal rules of teaching is to start with the familiar and proceed to the obscure, illustrating the obscure frequently with familiar examples. The study of local history makes this process occur almost automatically.

Support for the studies upon which this article is based came fron the National Endowment for the Humanities and the Faculty Research Committee of North Texas State University. A version of this paper was delivered to the Missouri Valley History Conference, Omaha, Nebraska, March 10, 1978. 
Undergraduates also share the fault of seeing history as static, as a series of more or less vivid set-pieces. Possibly that is the result of some professor describing his pet project at length, or it may stem from the term papers the students write, the topics of which are necessarily circumscribed in time and space. It is, after all, easier to visualize and describe something that is than something becoming or dissolving. The result is that the undergraduate sees history as a gallery--pictures at an exhibition--and fails to perceive the dynamism and change, the study of which is the proper goal of the historian. The close study of local history provides a manageable setting in which change can be seen, felt, followed, and evaluated, and the student can come to understand that society is, after all, never static.

Most local history is developed on the basis of either a county or city, and history presented in those terms does differ somewhat from traditional historical narratives. 11 To begin with, a county (or city) is artificial; no very definite boundaries separate it from its neighbors, and people pass back and forth across the frontiers with little personal shock. In greater distinction to traditional history, a county or city history has a dominant theme simply of progress through time, while the history of a treaty or a war or a social movement shifts its focus to the points where the greatest action is taking place. The "omniscient observer" of the traditional narrative moves about constantly, and, as a result of that constant shifting of attention to the exciting and significant, the event as a participant would have seen it is distorted. Furthermore, professors should realize that most of the topical approaches into which the discipline is usually divided--political, economic, social, religious, even, in some cases, military--can all be studied through local events. The variety of the human experience is not diminished when only local events are examined.

Equally important is the chance that local history allows for the student to get into the archival material that otherwise he would not see unless he undertook graduate training. Even at the graduate level he is likely to see primary sources only printed in massive volumes or reproduced on microfilm. In those forms they cannot convey the thrill of discovery that finding old diaries or ledgers in a bushel basket can do. It is the consciousness of that thrill of discovery, added to the pleasure that a skillfully presented logical analysis brings, which changes a student into an historian. The chance for archival research alone is enough to recommend local history to the attention of history faculties, especially at schools where libraries are not heavily funded.

The scholar who begins research in local history and who directs students into that field will find several unexpected traps waiting for the unwary, and he hazards committing one of the several sins peculiar to local history. The worst sin, one that has befouled many a county history, is the frenzied search for the first, the unique; writers fail to realize, especially once they are caught up in the hunt, that if it is difficult to deterinine when the first structure in the county was erected, then the question is not very important historically. Its very obscurity proves its naimportance, unless the loss of that information is the result of deliberate myth-making. Scholars have an obligation to warn students away from antiquarianism. Any subject being investigated has an autonomous and consistent internal logic into which the researcher will drift unless he is restrained and directed.

If the sin of antiquarianism can be seen as "chasing the trees," then the second sin is "losing the forest." One major function of local history is to test generalizations about the nation and the region. 12 If truth be told, there should be no such thing as "local" history. 13 Only insofar as local history illumines or reflects national or regional processes does it have significance, and then it has become something more than just a history of, 
say, Denton County, Texas. Seeing events against the national and regional background does not happen of itself; it must. be sought consciously.

"The past," writes Philip Jordan, "cannot be understood without a knowledge of the whole."14 And it is the responsibility of the scholar to develop that other information for the benefit of his own studies and to supply it to students so that they will have the knowledge of nation and state necessary to make the local study meaningful. At the same time, laborers in the national vineyards must realize that they cannot understand the whole they are examining without a knowledge of the local parts that comprise it.

Nevertheless, a county is individual and unique, just as a person who is the subject of a biography may be part of and product of his times yet be something other than only what they are.15 The scholar must never forget that he is investigating more than a slate on which is written only traces of greater events. He must understand the county's particular events and developments as well as the county's reflection of national and regional processes.

A danger to both scholar and student lies in the permanence and resilience of myth. Far too often, the poet's pen or local rumor has given "to airy nothing/ A local habitation and a name." It is altogether too easy to pass along a consensus of falsehood. In Denton County, Texas, for example, the first settlement was named in honor of the president of the colonization society that brought immigrants to the area. No local lore now recalls the name, possibly because the company fell into massive disrepute with the settlers. All the written records and oral tradition of the county now agree that the first settlement had a different name: 16 That myth is a harmless one, and the disappearance of the name is an historical datum of interest; in contrast, venomous myths about the horrors of Reconstruction, which actually had almost no direct impact on the county, have had unhappy social and political consequences. Those consequences are real, and need analysis; to perpetuate the myth itself would be shameful.

The problem seems to be that historians impress so heavily upon their students the belief that history must be documented that two things happen: students reject anything they cannot document immediately and easily, and they tend to believe that a documented statement is a true statement, which may be very unwise. Students and scholars alike tend to forget that the truth of a statement does not increase with its age; our forebears deceived themselves just as much as we do, and the falsehoods embedded in some county's history are less apt than national misconceptions to have been tested. Scholars and.students in local history, as much as in any other aspect of the discipline, must drive themselves to look for one more source, one more scrap of evidence or wisp of oral testimony, from which to work. 17

To sum up: local history should be a part of the college curriculum because the discipline itself is a proper and valuable one and because it can serve an important role in the education of students. It may be valuable in an unexpected way as we11. Professional historians tend to lose sight of their audience. They write articles of great distinction in sma11, prestigious journals for each other to read, in that way fulfilling one of their major obligations, which is to advance the frontiers of knowledge. But historians have a second obligation as great as the first: to cause their knowledge to be integrated into the mainstream of, society, and in meeting this second obligation historians are remiss. Local history in which Becker's Everyman has a natural interest is one place where scholar and public can communicate; "the history that lies inert in unread books," Becker reminds us, "does no work in the world."18 


\section{NOTES}

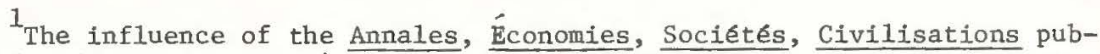
lished under various titles since 1929 should be noted. Some recent historians maintain the extreme position that "only local history can be true and sound." See Pierre Goubert, "Local History," in Historical Studies Today, ed. Felix Gilbert and Stephen R. Graubard (New York, 1972), 300.

2

This is in direct contradiction to the caveats Paul Leuilliot gives in "A Manifesto: The Defense and Illustration of Local History," in Rural Society in France. . . ed. Robert Forster and Orest Ranum, trans. E1borg Forster and Patricia M. Ranum (Baltimore, 1977), 10-12; this essay first appeared in Annales, Économies, Sociétés, Civilisations, XXII (JanuaryFebruary, 1967), 154-77.

${ }^{3}$ It is difficult to demonstrate logically why a history of Krum, Texas, should be called local history while a history of Dallas, Texas, from 1900 to 1920 should be called urban history. Sam B. Warner commented pejoratively that "except to the most discriminating reader, the usual shelf of urban history books looks like a line of disconnected local histories." See his "If All the World Were Philadelphia: A Scaffolding for Urban History, 17741930," American Historical Review, LXXIV (October, 1968), 27. Of course that is what they look like; that is what they are. On Warner's side, see Stephen Thernstrom, "Reflections on the New Urban History," in Historical Studies Today, ed. Gilbert and Graubard, 320-333.

${ }^{4}$ (Rev. ed., Cambridge, Massachusetts, 1974), I, 291.

${ }^{5}$ As Eric Goldman writes, "Many of the local studies of progressivism contribute importantly to the broader picture. . . ." See his Rendezvous with Destiny (New York, 1953), 477. An example of the type of work that Goldman had in mind is George E. Mowry, The California Progressives (Berkeley, 1951).

6 "In den Büchern stehen die Namen von Königen," wrote Bertolt Brecht in his great and bitter poem "Fragen Eines Lesenden Arbeiters," but those kings did not haul the blocks of stone that built the seven gates of Thebes; the lines about names written in bronze are from Ezra Pound, Canto XX.

7 Jesse Lemisch, "Listening to the 'Inarticulate'," Journal of Social History, III (Fall, 1969), 2.

8 The recent efforts of the Newberry Library and the continuing efforts of the American Association for State and Local History are helping to correct this situation. It should be noted that this article is the fruit of teaching local history, if only for the first time, at North Texas State University with my colleague E. Dale Odom.

${ }^{9}$ Clifford R. Lord, Teaching History with Community Resources (New York, 1964); Ralph Adams Brown and William G. Tyrel1, How to Use Local History, National Council for the Social Studies, Pamphlet $\# 3(1 \overline{961})$.

${ }^{10}$ Ibid., 1.

11 The county remains the most convenient unit for study because most government records are kept in terms of its boundaries. The American pioneer study of modern, professional county history is Merle E. Curti et al., Making of an American Community: Democracy in a Frontier County (Stanford, 1959). For a glimpse at the extent of the bibliography of county histories, see C.S. Peterson, Bibliography of County Histories of the 3111 Counties in the 48 States (Baltimore, 1935; reprinted 1946); and his Consolidated Bibliography 
of County Histories in Fifty States in 1961, Consolidated 1935-1961 (2nd ed.,

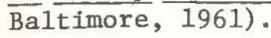

12 Note Goubert's comments about the role that local history can play in testing national generalizations, "Local History," 304-306.

${ }^{13}$ Philip D. Jordan, The Nature and Practice of State and Local History,

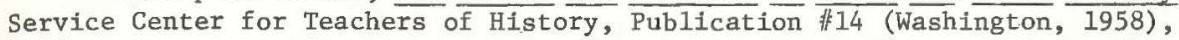
7; ". . historical research will tolerate no autarchy, "remarked Marc Bloch in The Historian's Craft, trans. by Peter Putnam of Apologie pour 1'histoire, ou métier d'historien (New York, 1962), 47.

14

Jordan, Nature and Practice, 8.

${ }^{15}$ Leuilliot, on the contrary, argues that it is necessary for practitioners of local history to recognize that local differentiation marks local history off from national concerns. See his "A Manifesto," 12-16.

${ }^{16}$ According to the tradition supported by Ed F. Bates, History and Reminiscences of Denton County (Denton, Texas, 1918), 13, it was Bridges Settlement; that myth was perpetuated in E. Dale Odom and Bullitt Lowry, A Brief History of Denton County, Texas (Denton, 1975), 4. That contemporaries called the town stewartsville is proved by the inscription on Map: Peters' Colony, 1852 (no scale), General Land office, Austin, Texas; two documents dated from Stewartsville in February 1848 in the William G. Hale Papers, Barker Texas History Collection, University of Texas at Austin, Texas, 2D256; and the fact that no contemporary dated any document from "Bridges Settlement."

${ }^{17}$ While historians are investigating the past, they should realize, their obligation to protect documents for the future. In their efforts to penetrate the nineteenth century, they are in danger of making the twentieth an historical wasteland for their successors. Plans must be developed and implemented for systematic preservation of recent materials; if current historians do not do it, no one will ever be able to.

${ }^{18}$ Carl Becker, Everyman His Own Historian (Chicago, 1966; reprint of 1935 edition), 252. 